\title{
THE IRON-DEFICIENCY ANAEMIA OF LATE INFANGY
}

\author{
BY \\ HAROLD W. FULLERTON, M.A., M.B., Сh.B., \\ Beit Memorial Research Fellow, \\ Department of Medicine, University of Aberdeen.
}

Since attention was drawn by the work of Mackay ${ }^{1}$ to the great frequency of anaemia during infancy, many investigators have studied the problem. As part of the large-scale investigation into the iron-deficiency anaemias of the poor classes, which has been carried out in Aberdeen 2, 3, haemoglobin estimations by the Haldane method have been made in 789 infants of all ages up to twenty-three months. A chart showing the course of the haemoglobin level according to age in 629 infants has already been published $^{3}$. Since that time haemoglobin estimations of 160 infants between the ages of nine and twenty-three months have been made, and in figure 1 the results obtained in the complete series of 789 infants are presented. The figure at each point on the curve represents the number of infants available for calculation of the average haemoglobin level for each age. It is seen that a very marked fall in haemoglobin level occurs during the first two months of life, namely, from a level of 145 per cent. at birth to $77 \cdot 6$ per cent. at two months. This fall is due to rapid reduction by haemolysis of the polycythaemic state present in the foetus as compensation for the low oxygen tension in the placental circulation. Following the slight rise in average haemoglobin level during the fourth month, the curve falls gradually until the eighth month. Thereafter there is a marked change, the haemoglobin level falling from 78.5 per cent. at the eighth month to 69.6 per cent. for the ages, eleventh month and twelfth to seventeenth months. From this point onwards the curve shows a rise which continues throughout childhood $^{3}$ and which is probably due to the increasing iron content of the diet during this period.

The percentage distribution of decimal ranges of haemoglobin for each age group is shown in table 1 . It is seen that the incidence of severe anaemia increases towards the end of the first year and continues to be high throughout the second year. The highest percentage of haemoglobin levels less than 60 per cent. in infants less than nine months of age is four, while for the age groups of nine months onwards the incidence of this degree of anaemia is $13,9,23,16$ and 12 per cent. respectively.

The course of the haemoglobin curve throughout infancy and the high incidence of anaemia from the ninth month onwards, are in agreement with the findings of several investigators. The difference between the haemoglobin levels of the infants examined in Aberdeen and the level of 
86 per cent. (Haldane) which is deduced by Mackay to be normal for infants of the age group five to fourteen months, is a striking demonstration of the frequency of anaemia among infants of the poor classes in that city.

It is not proposed to consider all the variations in haemoglobin level which occur throughout infancy from birth onwards. Attention will be confined to the iron-deficiency anaemia of infants from the ninth month to the end of the second year. Moreover, this anaemia will be considered only on the basis of iron-deficiency, without discussion of the numerous other

TABLE 1.

Percentage distribution of haemoglobin levels in 667 infants : 1 to 23 months.

\begin{tabular}{|c|c|c|c|c|c|c|c|c|c|c|c|c|}
\hline \multirow{2}{*}{$\begin{array}{c}\text { Age } \\
\text { (Months.) }\end{array}$} & \multirow{2}{*}{ Num- } & \multicolumn{10}{|c|}{ Hafmoglobin Rasge. } & \multirow{2}{*}{$\begin{array}{l}\text { Aver- } \\
\text { agoe } \\
\text { Hb. }\end{array}$} \\
\hline & & $20-29$ & $30-39$ & $40-49$ & $50-59$ & $60-69$ & $70-79$ & $80-89$ & $90-99$ & $100-109$ & $110-119$ & \\
\hline 1 & 12 & 0 & 0 & 0 & 0 & 0 & 42 & 8 & 8 & 25 & 17 & $90 \cdot 8$ \\
\hline 2 & 50 & 0 & 0 & 0 & 4 & 18 & 36 & 28 & 12 & 2 & 0 & $77 \cdot 6$ \\
\hline 3 & 49 & 0 & 0 & 2 & 2 & 16 & 39 & 27 & 12 & 2 & 0 & $77 \cdot 1$ \\
\hline 4 & 62 & 0 & 0 & 2 & 0 & 10 & 34 & 34 & 19 & 2 & 0 & $80 \cdot \tilde{5}$ \\
\hline 5 & 50 & 0 & 0 & 0 & 0 & 10 & 36 & 48 & 2 & 4 & 0 & $79 \cdot 8$ \\
\hline 6 & 61 & 0 & 0 & 0 & 3 & 15 & 46 & 31 & $\tilde{5}$ & 0 & 0 & $77 \cdot 9$ \\
\hline 7 & 48 & 0 & 0 & 2 & 2 & 4 & 52 & 35 & 4 & 0 & 0 & $77 \cdot 4$ \\
\hline 8 & 37 & 0 & 0 & 0 & 0 & 8 & 43 & 43 & 5 & 0 & 0 & $78 \cdot \tilde{5}$ \\
\hline 9 & 66 & 0 & l & 0 & 12 & 12 & 44 & 26 & 5 & 0 & 0 & $73 \cdot 8$ \\
\hline 10 & 56 & 0 & 0 & 2 & 7 & 27 & 36 & 27 & 2 & 0 & 0 & $72 \cdot 7$ \\
\hline 11 & 62 & 0 & 0 & 2 & 21 & 19 & 40 & 16 & 2 & 0 & 0 & $69 \cdot 6$ \\
\hline $12-17$ & 97 & 1 & 0 & 6 & 9 & 23 & 44 & 12 & 4 & 0 & 0 & $69 \cdot 6$ \\
\hline $18-23$ & 17 & 0 & 0 & 0 & 12 & 35 & 41 & 6 & 6 & 0 & 0 & $71 \cdot 5$ \\
\hline
\end{tabular}

factors which have been suggested as of etiological importance, e.g., deficiencies of copper $^{4,5,6}$, manganese ${ }^{7}$ and other metals, and of vitamin $\mathbf{C}^{8,9}$. The part which these other deficiencies play in disorders of haematopoiesis has been rendered prominent by the results of animal experimentation, but their effect in humans is far from certain. The haematological characters of the common anaemias of infancy and the excellent results of treatment with iron preparations containing only insignificant traces of other metals ${ }^{10}$, point unmistakably to iron deficiency as the factor of paramount importance.

\section{Etiology}

The etiology of the iron-deficiency anaemia of late infancy may be discussed under four headings (1) the type of milk feeding, (2) the effect of maternal iron deficiency, (3) the birth weight, and (4) the effect of infections. 
The type of milk feeding.-It has been clearly shown by Mackay ${ }^{1}$ that the type of feeding has an influence on the haemoglobin level in infancy. This conclusion is verified by the findings here presented in table 2 . For

TABLE 2.

AvERAGE HAEMOGLOBIN LEVELS ACCORDING TO THE TYPE OF FEediNG.

\begin{tabular}{|c|c|c|c|c|c|c|c|c|c|c|c|c|c|c|}
\hline $\begin{array}{c}\text { Age } \\
\text { (months) }\end{array}$ & 1 & 2 & 3 & 4 & 5 & 6 & 7 & 8 & 9 & 10 & 11 & 12 & 13 & $14-16$ \\
\hline Breast-fed ... & $\begin{array}{c}83.6 \\
(\overline{7})\end{array}$ & $\begin{array}{r}(8.2 \\
34)\end{array}$ & $\begin{array}{c}78.2 \\
(23)\end{array}$ & $\begin{array}{l}77.0 \\
(23)\end{array}$ & $\begin{array}{l}87.7 \\
(30)\end{array}$ & $\begin{array}{l}78.2 \\
(25)\end{array}$ & $\begin{array}{r}80.3 \\
(20)\end{array}$ & $\begin{array}{l}85.5 \\
\text { (1i) }\end{array}$ & $\begin{array}{l}75.6 \\
(28)\end{array}$ & $\begin{array}{l}74.2 \\
(18)\end{array}$ & $\begin{array}{l}73.7 \\
(19 ;\end{array}$ & $\begin{array}{l}73.1 \\
(17)\end{array}$ & $\begin{array}{l}71.8 \\
(14)\end{array}$ & $\begin{array}{l}72 \cdot 7 \\
(10)\end{array}$ \\
\hline Mixed feeding & 一 & $\begin{array}{c}77.8 \\
(6)\end{array}$ & $\begin{array}{r}87.5 \\
(4)\end{array}$ & $\begin{array}{l}81.0 \\
(15)\end{array}$ & $\begin{array}{l}77.8 \\
\text { (1i) }\end{array}$ & $\begin{array}{l}77.9 \\
(18)\end{array}$ & $\begin{array}{l}77.6 \\
(15)\end{array}$ & $\begin{array}{l}76.3 \\
(16)\end{array}$ & $\begin{array}{l}71.4 \\
(19)\end{array}$ & $\begin{array}{l}73.6 \\
(24)\end{array}$ & $\begin{array}{l}69.1) \\
(21)\end{array}$ & $\begin{array}{r}69.1 \\
(7)\end{array}$ & $\begin{array}{r}71.0 \\
(6)\end{array}$ & $\begin{array}{l}72.0 \\
(3)\end{array}$ \\
\hline Bottle-fed ... & $\begin{array}{c}89.3 \\
(3)\end{array}$ & $\begin{array}{c}73.6 \\
(5)\end{array}$ & $\begin{array}{c}71.5 \\
(4)\end{array}$ & $\begin{array}{r}84.0 \\
(10)\end{array}$ & $\begin{array}{c}73.5 \\
(2)\end{array}$ & $\begin{array}{c}74.6 \\
(8)\end{array}$ & $\begin{array}{c}71.5 \\
(8)\end{array}$ & $\begin{array}{c}73.2 \\
(5)\end{array}$ & $\begin{array}{c}67.1 \\
(9)\end{array}$ & $\begin{array}{r}65.8 \\
(12 !\end{array}$ & $\begin{array}{l}68.1 \\
(16)\end{array}$ & $\begin{array}{c}60.5 \\
\text { (11) }\end{array}$ & $\begin{array}{r}65.2 \\
(12)\end{array}$ & $\begin{array}{c}57.0 \\
(4)\end{array}$ \\
\hline
\end{tabular}

The figures in parenthesis represent the number of cases.

purposes of classification, 'breast-fed' infants comprise those in whom breast feeding was continued for at least eight months; ' mixed feeding' signifies breast feeding for at least one month, with artificial feeding during the rest of the period; and ' bottle-fed' infants are those who were artificially fed throughout or who were breast-fed for less than one month. It is seen that from the age of five months onwards, the average haemoglobin levels of the breast-fed infants are higher than in those who received ' mixed-feeding,' and considerably higher than in 'bottle-fed' infants.

While it is generally agreed that such differences are due to the higher iron content of human milk and the greater degree of ' availability' of this iron, there is a lack of data sufficiently reliable for a quantitative assessment of the difference between feeding with human and with cow's milk. In a previous communication ${ }^{11}$ it was estimated that the iron contained in human milk during the first six months of lactation was approximately $180 \mathrm{mgm}$. On this basis $240 \mathrm{mgm}$. may be taken to represent the iron intake of an infant during nine months' breast feeding. Figures for the iron content of cow's milk ${ }^{12,13,14,15}$ are for the most part considerably lower than those for human milk, but they show such marked variation that the calculation of an average figure would be of little value. Moreover, very few ironbalance experiments have been carried out in infants fed on breast milk and on cow's milk. Josephs ${ }^{16}$ found a positive iron balance of $6 \mathrm{mgm}$. per mensem in infants fed with cow's milk. Retentions of a similar magnitude were found by Langstein and Edelstein ${ }^{17}$ in babies fed with human milk, but only two experiments were performed on infants more than a few days old. On the other hand, Blauberg ${ }^{18}$ concluded that the iron retention in infants fed with human milk was five times greater than when cow's milk was used.

On the basis of the calculations presented under the next heading, the bluod iron content of an infant of nine months with a haemoglobin level of 
70 per cent. is approximately $270 \mathrm{mgm}$. The difference in average haemoglobin level between breast-fed and bottle-fed infants of this age is approximately 3 per cent., according to the figures of Mackay. The data here presented show a greater difference but the number of cases is smaller than in Mackay's series. A difference in haemoglobin level of 3 per cent. where the blood iron is $270 \mathrm{mgm}$. is equivalent to $11.6 \mathrm{mgm}$. iron. From what has been said, it appears quite probable that the total iron retention

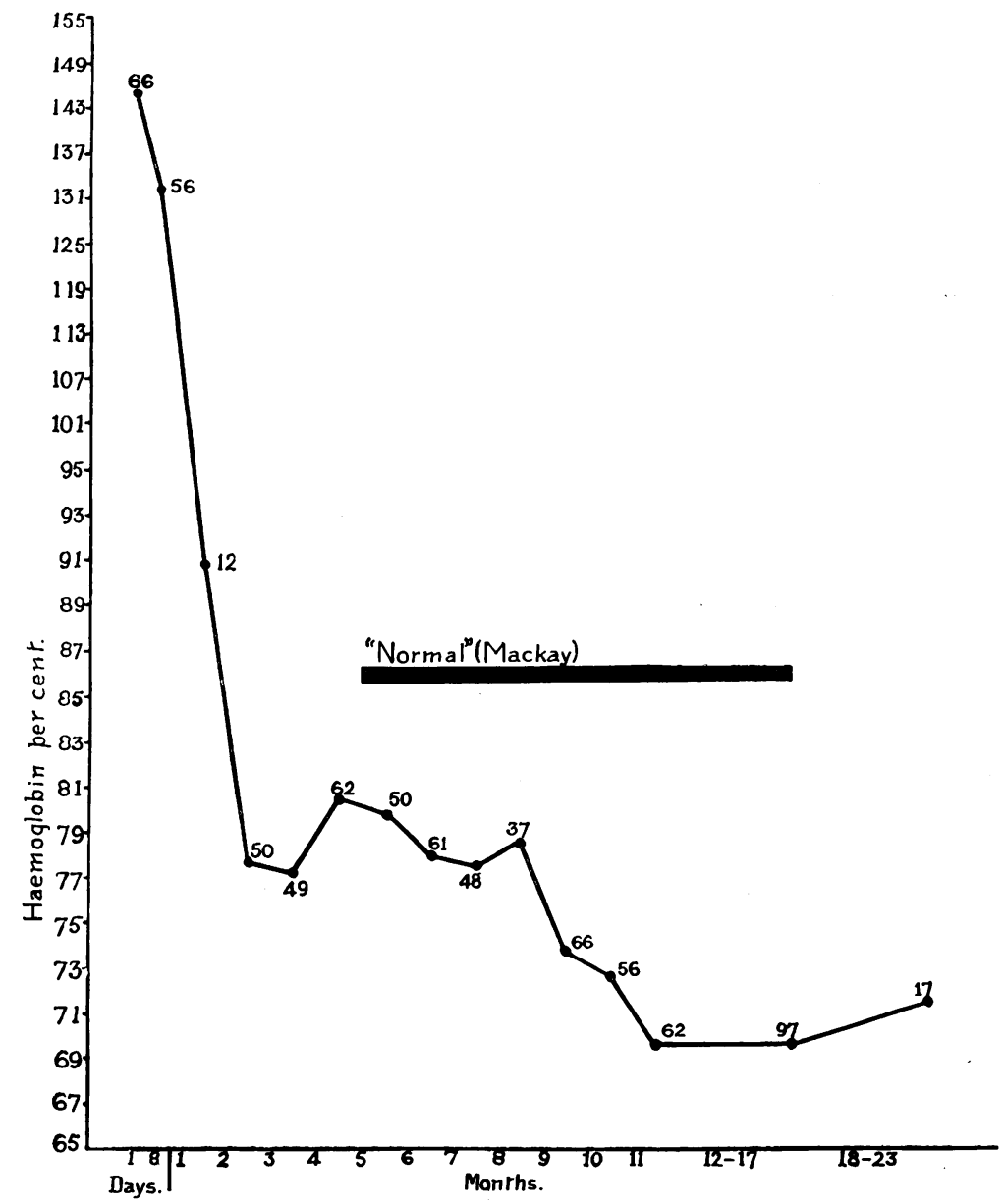

Fig. 1.-Average haemoglobin levels during infancy.

in breast-fed infants during the first nine months of life may exceed that of artificially-fed infants by such an amount. Hence if this difference in iron retention is reflected quantitatively in the haemoglobin level, the lower haemoglobin concentrations of 'bottle-fed' infants are readily explained.

In summary, it may be said that, although reliable data are insufficient for definite conclusions to be drawn, the greater degree of anaemia present in artificially-fed infants is probably due to a low iron retention. It should, 
however, be observed that this theory does not explain the fact that in Mackay's series the artificially-fed infants showed lower haemoglobin levels than breast-fed infants at all ages from birth to thirteen months. It will be shown later that, in tice absence of ir.sreased loss of iron from the body, iron deficiency does not occur in infants of average birth weight in the early months. This is exemplified by the present findings, for in table 2 it is seen that only from the fifth month onwards is there a consistent difference in the haemoglobin levels of breast-fed and artificially-fed infants.

The effect of maternal iron deficiency.-It is generally agreed that maternal anaemia does not influence the haemoglobin level of the infant at birth $^{19,20,21}$. The results obtained in 65 infants within twenty-four hours of birth and in 47 infants on the eighth day, support this conclusion (table 3).

TABLE 3.

Average haemoglobin Levels of infants on the First and Gighth DaYs aCcording TO MATERNAL HAGMOGLOBIN LEVEL.

\begin{tabular}{lll|r|r|r|r|r|r}
\hline Maternal Hb. .. & $\ldots$ & \multicolumn{2}{|c|}{$85+$} & \multicolumn{2}{|c|}{$75-84$} & \multicolumn{2}{|c}{74 and less. } \\
\hline Age (days) & $\ldots$ & $\ldots$ & 1 & 8 & 1 & 8 & 1 & 8 \\
\hline Average Hb. & $\ldots$ & $\ldots$ & $143 \cdot 3$ & $130 \cdot 1$ & $144 \cdot 0$ & $133 \cdot 6$ & $148 \cdot 1$ & $131 \cdot 1$ \\
\hline Number & $\ldots$ & $\ldots$ & 17 & 12 & 31 & 20 & 17 & 15 \\
\hline
\end{tabular}

It is the view of many authorities, 20, 22, 23, 24 that infants born of anaemic mothers become anaemic towards the end of the first year. The explanation usually given of this late development of anaemia in the infant, is that pregnant women suffering from iron deficiency supply inadequate liver stores of iron to the foetus, and that early exhaustion of these stores follows the milk feeding period of early infancy. It appears that the attractive nature of this hypothesis has rendered its acceptance general, although the scientific evidence in its favour is very scanty.

Bunge $^{25}$ was the first to stress the importance of the liver stores of iron at birth. He showed that the liver iron-content of new-born animals was proportionately much greater than in adults and presumed that in infants prolonged milk-feeding would result in anaemia after exhaustion of the iron stores of the liver present at birth. Also, the fact that anaemia occurs in the second and third generations of rats fed on an iron-poor diet ${ }^{26,27}$ is often adduced as evidence that maternal iron deficiency results in the development of anaemia in the offspring. Such results have been applied by many workers to an interpretation of the anaemia of infancy, without regard to the fundamental differences which exist between the iron metabolism of experimental animals and of humans. Rabbits increase their weight six-fold during the almost exclusive milk feeding of the first four weeks of life, and rats grow even more rapidly. An infant weighs approximately only two- 
and-a-half times its birth weight at the age of nine months. It is obvious, therefore, that the demand for iron during the period of milk-feeding is relatively much less in the infant than in the rabbit or the rat. Consequently it cannot be deduced that the liver store of iron present at birth is of equal importance in humans and in animals. Morever, the relation of total foetal weight to maternal weight is much higher in experimental animals than in the human. For example, a female rat weighing $250 \mathrm{gm}$. has on an average a litter of eight or nine young with a total weight of 36 to $45 \mathrm{gm}$., giving a foetal-maternal weight ratio of $1: 7$ to $1: 5 \cdot 6$. In the human the ratio is much less, approximately $1: 16$. Hence maternal iron deficiency is much more likely to result in foetal iron deficiency in rats than in infants. These simple calculations show clearly that inferences drawn from animal experimentation cannot be applied loosely to the study of the same problem in man.

The theory that maternal iron deficiency leads to a similar condition in the infant depends mainly on the experimental work on animals referred to briefly above, and on the investigations of Strauss ${ }^{20}$, which have been widely quoted. Strauss found that all the infants of twelve anaemic mothers developed anaemia towards the end of the first year. It has been shown, however, that the occurrence of iron deficiency in infancy is dependent on many different factors, e.g., birth weight and the rate of growth, the type of feeding and the incidence of infections. Hence, unless a series of cases is sufficiently large to exclude variations in these factors, little importance can be attached to the results.

During the course of these investigations the correlation between maternal and infantile anaemia has been especially studied. Haemoglobin estimations were made as far as possible at the same time in 223 mothers and their infants of ages nine to sixteen months (series 1). In 113 cases ( series 2) haemoglobin estimations of the mothers had been made also during

TABLE 4.

\begin{tabular}{|c|c|c|c|c|c|}
\hline \multirow{2}{*}{\multicolumn{2}{|c|}{$\begin{array}{c}\text { Maternal } \\
\text { Hb Ranges. }\end{array}$}} & \multicolumn{4}{|c|}{ Infants: Ages 9-16 months. } \\
\hline & & Number. & $\begin{array}{c}\text { Average } \\
\text { Birth Weight. }\end{array}$ & $\begin{array}{l}\text { Percentage } \\
\text { Bottle-fed. }\end{array}$ & Average $\mathrm{Hb}$. \\
\hline ب. & $\begin{array}{c}85 \text { per cent. }+ \\
75-84 \text { per cent, } \\
\text { Less than } 75 \text { per cent. }\end{array}$ & $\begin{array}{l}86 \\
43 \\
28\end{array}$ & $\begin{array}{l}7 \mathrm{lb} . \quad 7 \mathrm{oz} . \\
7 \mathrm{lb} . \quad 7 \mathrm{oz.} \\
7 \mathrm{lb.} \quad 0 \text { oz. }\end{array}$ & $\begin{array}{l}25 \\
32 \\
58\end{array}$ & $\begin{array}{l}70.6 \\
68.6 \\
70.6\end{array}$ \\
\hline 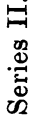 & $\begin{array}{c}80 \text { per cent. }+ \\
70-79 \text { per cent. } \\
\text { Less than } 70 \text { per cent. }\end{array}$ & $\begin{array}{l}45 \\
41 \\
27\end{array}$ & $\begin{array}{l}7 \mathrm{lb} . \quad 5 \mathrm{oz} . \\
7 \mathrm{lb} . \quad 7 \mathrm{oz} . \\
7 \mathrm{lb.} 12 \mathrm{oz} .\end{array}$ & $\begin{array}{l}26 \\
35 \\
29\end{array}$ & $\begin{array}{l}69.2 \\
70.3 \\
64.5\end{array}$ \\
\hline
\end{tabular}

the pregnancy. None of the mothers or infants in these series had received iron therapy. In both series the mothers were divided into three groups, 
' normal,' ' mildly anaemic,' and ' severely anaemic.' When haemoglobin estimations of the mothers were made from nine to sixteen months after the birth of the infant (series 1) the haemoglobin ranges are 85 per cent. and over, 75 to 84 per cent. and less than 75 per cent. In series 2 the ranges are 5 per cent. less for each group owing to the physiological hydraemia of pregnancy. In the infants the average haemoglobin levels have been calculated and are presented in table 4. In series 1 the infants of anaemic mothers show the same average haemoglobin level as the infants born of non-anaemic mothers. Series 2 shows that the average haemoglobin level is 4.7 per cent. lower in infants of anaemic mothers than in those of normal mothers. The significance of this finding is partly counteracted by the fact that the infants of normal mothers are slightly more anaemic than those of mildly anaemic mothers. Therefore serious doubts must exist as to whether either of these slight differences is significant.

It has already been pointed out that the other factors which tend to cause anaemia in infants must be controlled before deductions can be drawn from such investigations. Accordingly the average birth weight and the frequency of 'bottle feeding' have been calculated for each group and are included in the table. There is little variation in the average birth weight of the different groups, but it is interesting to note that in both series anaemic women were less often able to breast-feed their infants than non-anaemic women. This is a point which warrants further investigation. In summary, these results suggest that infants of anamic mothers are slightly, if at all, more liable to develop anaemia than those of non-anaemic mothers.

It is convenient at this stage to consider briefly the quantitative aspect of iron deficiency in infancy. It has already been pointed out that the haemoglobin level at birth bears no relation to maternal anaemia. The high haemoglobin level of new-born infants is generally agreed to be a compensation for the low oxygen tension in the placental circulation. The reaction of the human organism to low oxygen tension, e.g., in individuals living at high altitudes, appears to be two-fold, comprising polycythaemia and increase in blood volume ${ }^{28}$. Therefore, it is to be expected that the blood volume in infants is high. This question has been investigated by several workers $^{29,30,31}$. Lucas and Dearing found that the blood volume of thirty infants not more than two weeks old varied over a wide range, but was, on an average, 14.7 per cent. of body weight. A decrease occurs during the first year of life, but the available data are insufficient to show the rapidity and extent of this fall. At one year the percentage blood volume still exceeds the figure for adults. Omission to consider the high blood volume during infancy, and particularly at birth, has led authors to adopt an erroneous conception of the iron metabolism of infants.

Taking $3 \cdot 1$ kilogrammes as the average weight, 145 per cent. (Haldane) as the average haemoglobin level, 14.7 per cent. of body weight as the blood 
volume, and $50 \mathrm{mg}$. per cent. as the iron content of blood of 100 per cent. haemoglobin, it is found that the iron content of the blood at birth is:-

$$
\begin{aligned}
& \text { Blood vol. } \times \frac{\text { Hb. per cent. }}{100} \times 50 \mathrm{mgm} . \\
& \text { i.e. } \frac{31 \times 14.7}{100} \times \frac{145}{100} \times 50=330 \mathrm{mgm} .
\end{aligned}
$$

The accuracy of this figure depends mainly on the magnitude of the blood volume, and, since only few determinations have been made, and these show variation, the figure can be presented merely as an approximation. Nevertheless it may safely be deduced that usually at least 80 per cent. of the iron content of a new-born infant is present in the haemoglobin molecule.

Various figures are found in the literature for the non-haemoglobin iron content of the liver at birth. Gladstone ${ }^{32}$ found an average of approximately $30 \mathrm{mgm}$., Sheldon $50 \mathrm{mgm} .{ }^{3.3}$ and Toverud $60 \mathrm{mgm} .{ }^{34}$. It should be pointed out that in such investigations failure to obtain the liver in a blood-free state prior to analysis is probably frequent. This would tend to give results that are too high. For purposes of calculation, however, $50 \mathrm{mgm}$. will be taken to represent the average iron store of the liver at birth.

If the tissues of the infant, exclusive of blood and liver, contain the same proportion of iron as those of the adult $(23 \mathrm{mgm}$. per kilogramme body weight) ${ }^{3.5}$, it may be calculated that their total iron content is approximately $70 \mathrm{mgm}$. Josephs ${ }^{36}$, as a result of experiments on rats, deduced that the tissue iron in the human was less than $5 \mathrm{mgm}$. per kilogram, but the figure adopted here is approximately in agreement with the findings of Hahn and Whipple in $\operatorname{dogs}^{37}$. Hence it may be concluded that the iron content of a new-born infant is distributed as follows :-

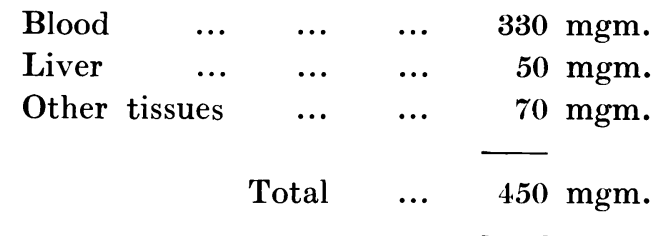

A total of $4.50 \mathrm{mgm}$. is slightly in excess of the generally accepted figure ${ }^{11}$, but it has already been observed that the figure for blood volume (14.7 per cent.) is based on relatively few results and it is obvious that a lower figure would reduce the blood iron. The above distribution of the iron content of the new-born infant may therefore be taken as approximately accurate.

It has been established that the iron released by the haemolysis which produces the rapid fall in haemoglobin during the first two months of life, is largely conserved ${ }^{38}$. This is shown by the balance studies of Josephs ${ }^{16}$ and Langstein and Edelstein ${ }^{17}$; and Gladstone ${ }^{32}$ has demonstrated that the released iron is stored in the liver. Apparently the total loss during the period of rapid haemolysis is very small, approximately $4 \mathrm{mgm} .{ }^{16}$. From the end of the second month onwards the infant is in a positive iron balance of approximately $6 \mathrm{mgm}$. per mensem ${ }^{16,17}$. 
It is now of interest to apply these conclusions to an analysis of the iron content of breast-fed infants at the age of nine months. For this purpose calculations will be based on the following figures:-

$$
\begin{aligned}
& \text { Blood volume }=10 \text { per cent. of body weight. } \\
& \text { Body weight }=7.75 \mathrm{kgm} . \\
& \text { Hb. (Haldane) }=86 \text { per cent. }
\end{aligned}
$$

On this basis the blood iron $=\frac{\text { Blood vol. }}{100} \times \frac{\text { Hb. per cent. }}{100} \times 50 \mathrm{mgm}$.

$$
=\frac{775}{100} \times \frac{86}{100} \times 50 \mathrm{mgm} .=333 \mathrm{mgm} .
$$

The iron content of the tissues (exclusive of the liver) may be calculated as having increased proportionately to the body weight, i.e., tissue iron $=\frac{775}{\mathbf{3 1 0}} \times \mathbf{7 0}=175 \mathrm{mgm}$. Hence the total iron content of the infant, exclusive of the liver iron store, is $508 \mathrm{mgm}$. It is apparent, then, that if the liver store of iron present at birth $(50 \mathrm{mgm}$.) has been utilized for new haemoglobin formation, a retention of $58 \mathrm{mgm}$. over a period of nine months milk feeding is necessary for the maintenance of a haemoglobin level of 86 per cent. at nine months. From the discussion presented above, it would appear that retentions of this magnitude occur in breast-fed infants. Hence it may be concluded that in infants of normal birth weight an ideal haemoglobin level of approximately 86 per cent. should be attained at the age of nine months if the liver store of iron present at birth is completely utilized. It should be stressed that this calculation applies only to hypothetically ' perfect' infants, that is, those who are of normal birth weight, are breast-fed, and who have suffered from no infections, gastrointestinal upsets or even teething pyrexia prior to the haemoglobin estimation.

Although it is impossible to claim a great degree of accuracy in the above calculations, owing to insufficient information regarding blood volume changes and iron balances, it is clear that the important iron stores in the new-born infant are present in circulating haemoglobin and not in the liver. Indeed, if it is presumed that no liver iron reserve is present at birth and that this deficit of $50 \mathrm{mgm}$. is wholly reflected in a lower haemoglobin level, then the blood iron at nine months would be $283 \mathrm{mgm}$. (333-50 mgm.) which represents a haemoglobin level of 73 per cent. Obviously, therefore, a partial deficiency in the liver iron store present at birth can have only a slight effect on the haemoglobin level in later infancy. It may be concluded, then, that not only do these results fail to show any significant correlation between the common degrees of maternal iron deficiency and anaemias in late infancy, but also that the hypothesis generally upheld as 
explaining such a correlation is unconvincing when examined on a quantitative basis.

The question may be considered also from the standpoint of the maternal iron content. The hypothesis under consideration implies that a woman with iron deficiency supplies to the foetus sufficient iron for a normal haemoglobin level, and, presumably, normal tissue iron at birth, a total of $400 \mathrm{mgm}$., but fails to supply the $50 \mathrm{mgm}$. which is the average liver store of iron; i.e., in the presence of iron deficiency the maternal organism always transfers to the foetus 90 per cent. of its normal complement of iron, but fails to transfer the last 10 per cent. necessary for liver storage, an amount which would result in an insignificant alteration in the maternal iron content. Such a theory is untenable. If maternal iron deficiency is reflected in the infant, probably it acts in other ways, such as a lowering of the blood volume. The evidence presented in a previous paper on the iron deficiency anaemias of pregnancy ${ }^{39}$, showed that the iron drain of the foetus is not sufficiently large to cause a marked effect on the maternal iron content. Therefore, the iron content of the new-born infant is probably independent of that of the mother, except, perhaps, in the most severe degrees of maternal iron deficiency. In this connexion it is interesting to note that the infants of the eight mothers most anaemic during pregnancy (haemoglobin less than 55 per cent.) had an average haemoglobin of 65.5 per cent. when approximately one year old, i.e., less than 4 per cent. below the general average for this age.

Further support of these conclusions is afforded by the effect on the infant of iron treatment of the mother during pregnancy. Ferrous sulphate (nine grains a day) was taken during pregnancy for periods varying from one to four months by 56 of the mothers whose infants were examined when nine to sixteen months old. The effect of this therapy in a series of pregnant women, which included the 56 cases here considered, has been discussed in a previous communication ${ }^{39}$. It was shown that the haemoglobin levels of the iron-treated women rose during pregnancy and those of the non-treated women fell. The average haemoglobin level of the infants of 56 women treated during pregnancy was $70 \cdot 3$ per cent., while that of 167 infants whose mothers received no treatment was $68 \cdot 8$ per cent. All the infants were nine to sixteen months old at the time of examination. The average birth weight of the infants whose mothers received iron therapy in pregnancy was $7 \mathrm{lb} .9 \mathrm{oz}$., and 28 per cent. of the infants were artificially fed. The corresponding figures for the control group were $7 \mathrm{lb} .5 \mathrm{oz}$. and 34 per cent. Hence the slightly higher haemoglobin level of the infants of treated mothers may be due to the higher average birth 
weight and the lower incidence of artificial feeding, and not to any direct effect of the iron therapy.

Birth weight.-The investigations of many authors have shown that infants of low birth weight develop an iron-deficiency anaemia ${ }^{1,}$ 16, 40, 41, 42. The average haemoglobin levels of 222 infants of ages nine to twenty-three months, arranged according to birth weight, are presented in table 5. It is clearly seen that the lower the birth weight the lower is the haemoglobin level in late infancy. The discussion presented in the previous section makes the reason for this correlation evident. The smaller the infant at birth, the lower is the absolute iron content of circulating haemoglobin. Consequently, less iron is conserved following post-natal haemolysis, to be utilized in the new haemoglobin formation which accompanies growth. It should be emphasized, however, that this explanation depends on the fact that infants of low birth weight grow more rapidly in relation to birth weight than infants of normal weight. If this were not so there would be no greater tendency for the development of iron deficiency in infants small at birth, unless other factors such as increased susceptibility to infection were operative. The importance of the rate of growth in contradistinction to the birth weight has been stressed by Mackay $^{1}$ and by Josephs ${ }^{16}$.

TABLE 5.

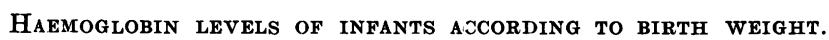

\begin{tabular}{lr|r|r|r|r|r|r|r|r}
\hline Birth weight (lb.) ... & 2 & 3 & 4 & 5 & 6 & 7 & 8 & $9+$ \\
\hline Number of cases &.. & 2 & - & 10 & 8 & 32 & 47 & 51 & 16 \\
\hline Average Hb. &.. & $41 \cdot 0$ & - & 53.9 & 62.4 & 66.5 & 69.2 & $72 \cdot 1$ & $71 \cdot 0$ \\
\hline
\end{tabular}

A hypothetical example makes it clear that a slightly increased rate of growth may result in a considerable reduction in the haemoglobin level. It has already been calculated that an infant weighing $3.1 \mathrm{kgm}$. at birth and $7.75 \mathrm{kgm}$. at nine months, should have a haemoglobin level of 86 per cent. at nine months if a liver store of $50 \mathrm{mgm}$. and a dietary iron retention of $58 \mathrm{mgm}$. are utilized for haemoglobin formation. The haemoglobin level of an infant similar in all respects except that the weight at nine months is $9 \mathrm{kgm}$. instead of $7.5 \mathrm{kgm}$., would theoretically be 68 per cent. In this calculation the tissue iron of the second infant is taken as representing the same relation to body weight as in the first infant. Therefore the haemoglobin level at nine months is 18 per cent. less when the weight at nine months is 2.9 times the birth weight instead of 2.5 times. Absolute accuracy cannot be claimed for these figures, but since the only respect in which the second infant differs from the first is in the weight at nine months, the effect on the haemoglobin level of an increase in rate of growth becomes evident.

Although the correlation between anaemia and low birth weight is wellmarked, it should be realized that the factor of real importance is not 
actually the weight but the total iron content which depends mainly on the blood volume. The correlation holds because the birth weight may conveniently be taken as a rough index of the total blood volume. Nevertheless the work of Lucas and Dearing ${ }^{29}$ has shown that considerable variations in blood volume can occur irrespective of the birth weight. Hence it is possible that a new-born infant of $5 \mathrm{lb}$., with a high percentage blood volume, may have a higher total blood iron than an infant of $7 \mathrm{lb}$. with a low blood volume. This may explain why some infants of low birth weight maintain a high haemoglobin level in spite of rapid growth.

Since it is believed that the deposition of iron in the liver occurs especially during the last months of gestation ${ }^{35}$, many authors consider that the iron-deficiency anaemias, so frequent in premature infants and twins, is due to exhaustion of liver iron stores which are deficient at birth. From what has been said with regard to the effect of low birth weight, it is clearly unnecessary to postulate such a deficiency. Moreover, it has already been demonstrated that a low iron reserve in the liver at birth can influence only to a slight extent the haemoglobin level in late infancy. With more accurate data than are at present available regarding the blood volume changes and the retention of iron throughout infancy, it would be possible to construct a table showing the expected haemoglobin levels at different ages, according to the weight of the infant at birth. In conclusion it may be said that the anaemias of premature infants and twins is a direct consequence of two factors-a low iron content at birth and rapid growth.

The effect of infections.-It is generally agreed that infections during infancy tend to cause anaemia. Nevertheless there appears to be a lack of statistical information on this point, and it is not definitely known whether certain types of infection cause a more severe anaemia than others. Mackay ${ }^{1}$ believes that most slight infections do not influence the haemoglobin level, but that severe illnesses of many types, especially pyogenic diseases, are followed by anaemia. During the course of this investigation the history of illnesses suffered by the infants examined was obtained from the mother. In approximately fifty per cent. of the cases diseases of an infective nature had occurred. These were of various types, the most common being nasal catarrh, bronchitis, measles and otitis media. Analysis of the data is shown in table 6 . It is seen that there is no significant difference between

TABLE 6.

A Verage hafmoglobin level.s of infants aCCORIINg to history of infections.

\begin{tabular}{|c|c|c|c|c|c|c|c|c|c|c|c|c|c|}
\hline $\begin{array}{c}\text { Age } \\
\text { (Months) }\end{array}$ & & 1 & 2 & 3 & 4 & 5 & 6 & 7 & 8 & 9 & 10 & 11 & $12-1718 \cdots 23$ \\
\hline \multirow{2}{*}{$\begin{array}{c}\text { No history } \\
\text { of } \\
\text { infections }\end{array}$} & & 8 & 29 & 22 & 32 & 27 & 26 & 20 & 16 & 28 & 26 & 35 & $44: 3$ \\
\hline & Aver. Hb. & 85.1 & 78.7 & 78.1 & 79.5 & 79.1 & 76.8 & 77.7 & 78.3 & 71. & 73.2 & 70.3 & $69.2 \quad 79.3$ \\
\hline \multirow{2}{*}{$\begin{array}{l}\text { History of } \\
\text { infections }\end{array}$} & Number & 1 & 13 & 7 & 18 & 14 & 21 & 20 & 14 & 29 & 22 & 22 & 39 \\
\hline & Aver. $\mathrm{Hb}$. & 71.0 & 78.8 & 80.3 & 82.7 & 82.6 & 80.3 & 97.5 & $7 \% .0$ & 74.6 & 72.6 & 70.5 & $67.8 \quad 72.0$ \\
\hline
\end{tabular}


the haemoglobin levels of infants with a history of infections and those of infants who suffered from no illnesses. Such a result is indeed surprising when it is realized that apart from the effect of infections in producing anaemia de novo, anaemic infants, according to Mackay, show a higher morbidity rate than non-anaemic infants.

The results of this part of the investigation may be criticized on several grounds. In the first place, the intelligence of the mothers was not high and it is probable, therefore, that they did not include mild illnesses in their account of the infants' health. The importance of this point will appear later when it will be shown that falls in haemoglobin level may accompany pyrexia due to teething, conjunctivitis and other mild infections. Secondly, the information was obtained at busy out-patient centres by a variety of observers, including unqualified health visitors. It is to be expected, therefore, that considerable differences existed in the care with which a history was elicited from the mothers. Finally, the period elapsing between an infective illness and the haemoglobin determination was in many cases unknown. Thus the investigation was uncontrolled in several respects. In order to check the reliability of these histories, health visitors were asked to make careful inquiry into the incidence of illnesses of all types in infants of the same social status as those discussed in this article. It was found that illness had occurred during the first year of life in 87 per cent. of 428 infants whose mothers were specially interrogated. This suggests that the failure to obtain a correlation between anaemia and infections may be largely due to the fact that almost all the infants had infective illnesses, although a positive history was given in less than 50 per cent of the cases. Nevertheless, if mild infections may cause anaemia, severe infections such as would be noted by mothers and health visitors should logically produce still more anaemia, and therefore, a correlation between haemoglobin levels and a history of illnesses would have been expected. The controlled observations to be described later leave little room for doubt that infections produce anaemia, and it is concluded that clinical data collected routinely by workers in busy out-patient clinics may be of little value.

Definite information regarding the rôle of infections is afforded by the result of an investigation carried out in an institution in Aberdeen. Twentysix infants of ages six to twenty-two months were observed for approximately one year while under medical supervision and excellent dietetic and hygienic conditions. When the investigation began in December, 1934, the infants showed a wide haemoglobin range from 46 to 89 per cent. The average haemoglobin level was $67 \cdot 2$ per cent. and 26.9 per cent. of the infants were severely anaemic (haemoglobin less than 60 per cent.). In an attempt to estimate the therapeutic efficiency of small doses of ferrous salts, three grains of ferrous sulphate in tablet form was given daily to each infant, in divided doses. This treatment was in most cases continuous from January to May, 1935. Since it was found that many infants refused to swallow the tablets, a solution of ferrous sulphate in $\mathbf{5 0}$ per cent. glucose was made and given in doses of 1 drachm t.i.d. (total daily dose $=3$ grains) from May to
October. 
The average haemoglobin levels of the infants throughout 1935 are plotted in figure 2. It is seen that after an initial rise in haemoglobin level from 67.2 per cent. to 79 per cent. during the first five weeks, a marked fall occurred and was followed by a slow and irregular rise. The lowest average haemoglobin level coincided with an epidemic of naso-pharyngeal and bronchial catarrh in late April and May, which affected practically every child in the Home. Whilst this may be taken as strong evidence that the epidemic was directly responsible for the low haemoglobin level in May, the fall of the curve in February and March, and the slow rise after the epidemic, still require explanation. It was found that in addition to the epidemic, infections of various types were present in individual cases throughout the year, and the course of the average haemoglobin level therefore does not reflect accurately the effects of iron therapy. Accordingly, the data regarding each infant were analyzed separately, and it became apparent that almost in every case infections had occurred after the end of January. Moreover, the haemoglobin level was lowered with unfailing regularity after each infection. The types of illness included bronchopneumonia, otitis media, chicken-pox, tonsillitis and enlarged neck glands. It is not practicable to publish in detail the protocols of all the infants, but in figure 3 are shown five typical examples. Although haemoglobin estimations were made in each infant at approximately monthly intervals, for simplicity in presentation all of these values are not charted in the figure. In each case the course of the haemoglobin level during a period of infection is represented by a straight line joining the haemoglobin value obtained before the onset and the first value determined after the infection had ceased. A similar plan is followed in showing the course of the haemoglobin level during periods when no infection occurred. The marked falls in haemoglobin level during the course of infections are clearly shown. The curve B. K. illustrates the effect of two separate infections, each being accompanied by a fall in haemoglobin and succeeded by a rise.

In the case histories of three infants, pyrexia attributed to teething was noted. In each case the haemoglobin fell during the period of pyrexia, the extent of the fall varying from 4 per cent. to 21 per cent. In another infant conjunctivitis with pyrexia caused a fall in haemoglobin level of 10 per cent. These findings suggest that mild disturbances are accompanied by a fall in haemoglobin level. The results obtained from this investigation leave no room for doubt that infections of various types cause marked falls in haemoglobin level even during iron therapy. Moreover, no response to therapy may occur until several weeks after pyrexia has subsided.

The mode of action of infections in producing anaemia is not clear Probably iron deficiency is a factor, since it has been shown by Josephs ${ }^{16}$ that a negative iron balance occurs during a period of infection. However, the rapid falls in haemoglobin level suggest that the toxins of infective processes cause, in addition, an inhibition of blood formation in infants.

\section{Discussion}

From what has already keen said regarding the anaemia of late infancy, it appears that the following conclusions are warranted:-

(1) The iron content of the infant at birth is of great importance in determining the onset of iron deficiency.

(2) Breast-fed infants are less liable to anaemia than artificially-fed infants.

(3) The common infective illnesses of infancy produce a rapid fall in haemoglobin level and may inhibit blood regeneration for a considerable time after the disappearance of clinical evidence of infection. 


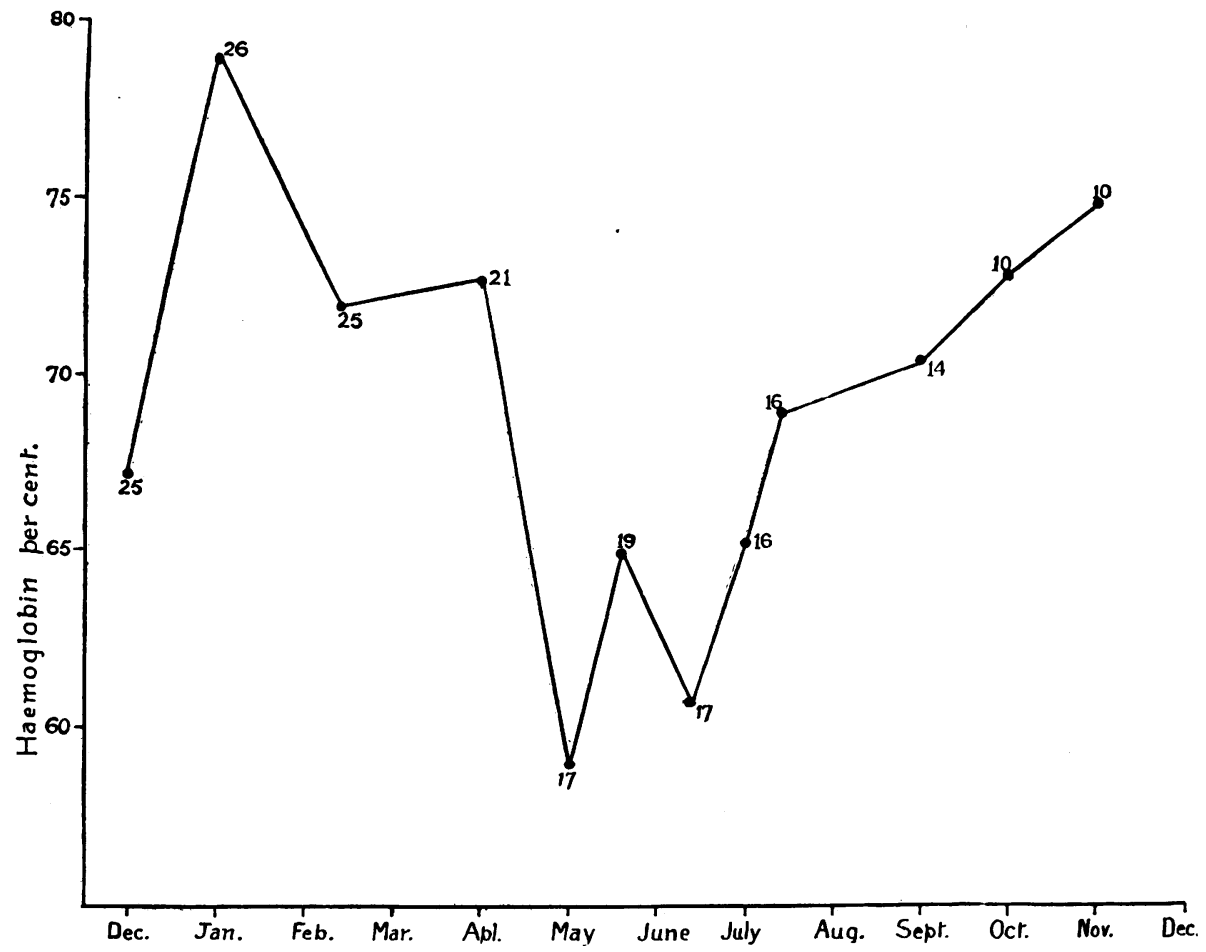

Fig. 2.-Effect of catarrhal epidemic on average haemogiobin levels.

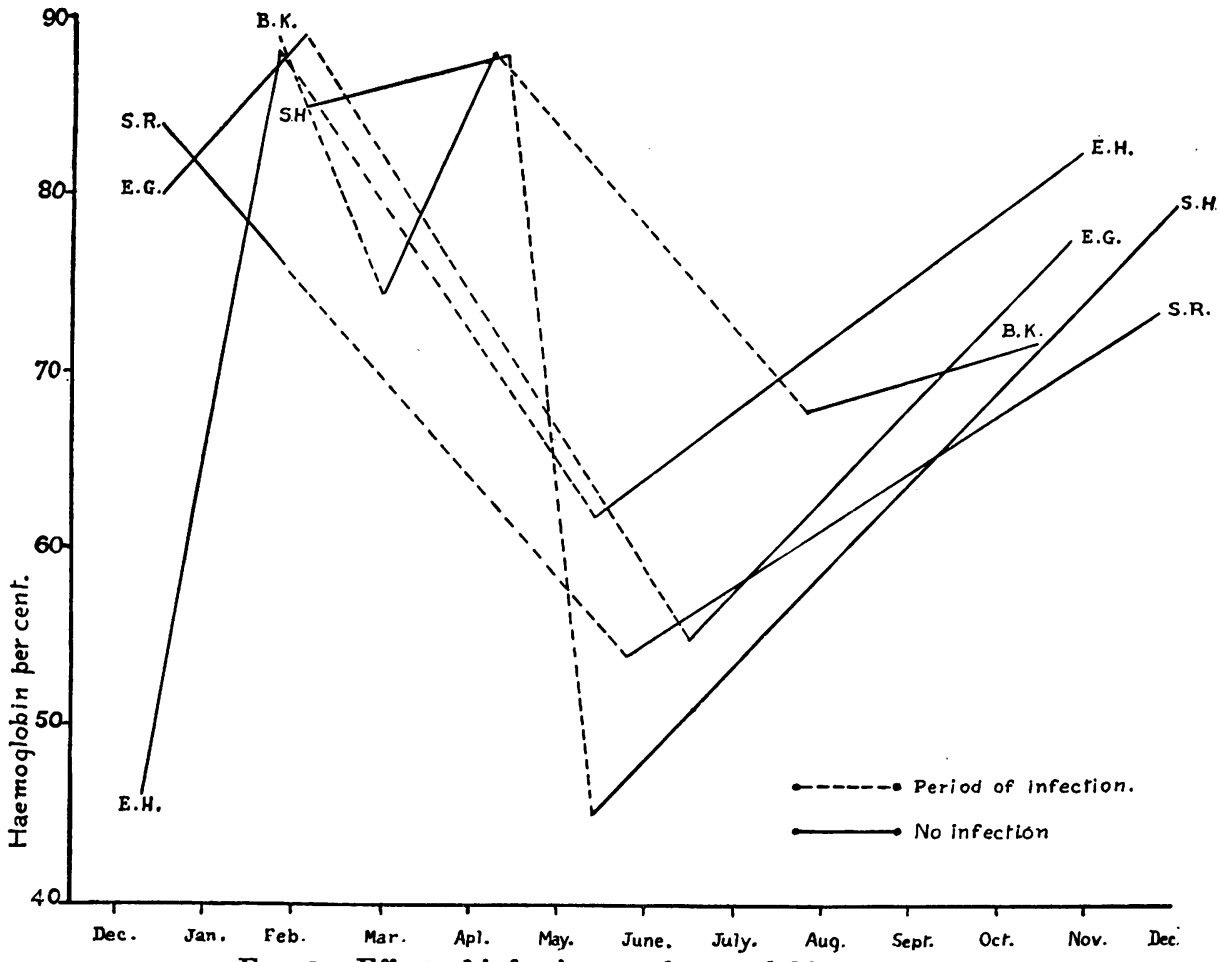

Fic. 3,--Effect of infections on haemoglobin level. 
It has been indicated that a breast-fed infant of normal birth weight and free from all illnesses should not theoretically develop iron deficiency before the age of nine months. After this time the increasing iron content of the diet presumably should maintain the haemoglobin at a normal level. It has been clearly shown that this ideal is rarely attained by infants of the poor classes in Aberdeen. Actually only 13 per cent. of infants between the ages of nine and twenty-three months had haemoglobin levels of 80 per cent. or more. Therefore the factors causing anaemia must be prevalent in the class of infants examined. The incidence of low birth weight and artificial feeding has already been discussed, and it has been shown that a large proportion of the infants had suffered from infections. In an attempt to discover if other factors were of importance in determining the development of anaemia, analysis was made of the infants of ages nine to twenty-three months who weighed at least $7 \mathrm{lb}$. at birth, were breast fed for not less than eight months and who, according to the histories given by the mothers, had no infections during four months prior to examination. Only 56 infants fulfilled these conditions and of these 8 (14.3 per cent.) had haemoglobin values less than 70 per cent., and $2(3.6$ per cent.) were less than 60 per cent. Therefore, whilst the incidence of anaemia is much less in this group than in the complete series, it is still sufficiently high to lead to the suspicion that factors other than those considered may play an etiological rôle. The explanation of these cases of anaemia may lie in one or other of the following possibilities :-

(1) Recent work has indicated that achlorhydria is of fairly frequent occurrence during infancy and plays an important part in producing iron deficiency $^{44,45,46}$. It is therefore possible that achlorhydria was present in some of the anaemic infants in whom no other etiological factor was found.

(2) It has already been emphazied that the birth weight gives only an approximate estimate of the iron content of the infant at birth, owing to the large variations in percentage blood volume which occur. Hence, some of the infants of normal birth weight who developed anaemia may have had a low blood volume.

(3) The unreliable nature of the histories of the infants, as given by their mothers, has already been discussed, and it has been observed that infections regarded as mild might have been overlooked.

(4) It is probable that the type of diet given to infants after weaning varies within wide limits in regard to its iron content. Hence some cases of anaemia during the second year may be due to a low dietary iron intake.

The anaemia discussed in this communication is frequently called the ' nutritional anaemia of infancy,' and many cases in which the etiological factor of importance is low birth weight or infective processes, have been erroneously classified under this heading. The quantitative aspect of the iron metabolism in infancy indicates that a deficient iron intake during the first nine months has not a marked effect on the haemoglobin level. On the basis of the figures already presented, it may be calculated that an infant of average weight, haemoglobin level and blood volume at birth, will attain a 
haemoglobin percentage of 71 at the age of nine months, when no dietary iron has been retained during this time. However, as growth continues, a deficient dietary iron intake becomes of increasing importance, and possibly many cases of severe anaemia during the second year are attributable to this factor. There is, however, little information regarding the absolute and ' available' iron contents of the diets of infants after weaning, and the degree of variation in different classes of the population has not been clearly established. Therefore the importance of a deficient iron intake in infancy can be at present only a matter of conjecture. It ought to be emphasized, however, that anaemia should be explained on the basis of deficient iron intake only in cases where the birth weight was normal, and where no infections have occurred; and it should be borne in mind that severe anaemia due to dietary deficiency alone is unlikely to occur during the first year. There is, therefore, usually little justification for applying the term ' nutritional' to the common anaemias of infancy.

The frequency of anaemia in infancy has led to the suggestion that the dietary regime commonly adopted in this country should be altered by the introduction of iron-rich foods in larger quantity and at an early age. The advisability of such a change is a matter for paediatricians to decide. Certainly, from the standpoint of iron deficiency alone, there is no necessity to institute drastic dietary revisions. Medicinal iron, when properly prescribed, is taken without difficulty by infants, and the effects of such therapy on haemoglobin regeneration are likely to be more satisfactory than any that could be obtained by dietary measures. The great frequency of anaemia in infancy, and the knowledge of its etiology which has been gained in recent years, suggest that a haemoglobin estimation should be made in all infants at the age of three months. Where such a procedure cannot be carried out, a course of iron therapy should be given routinely at the age of three months to all infants of birth weight less than $7 \mathrm{lb}$., and in cases of artificial feeding. Moreover, iron therapy should be instituted after illnesses of an infective nature, and should be continued for at least two to three months. Such measures would undoubtedly effect a marked improvement in the health of infants, since iron deficiency increases susceptibility to infective illnesses and may cause retardation of growth. A point of practical importance which should be borne in mind is the difficulty of diagnosing anaemia in infants without actual estimation of the haemoglobin percentage. This applies particularly to infants who are regularly placed in sunshine and fresh air. For example, the general appearance of the infants examined in the institution mentioned above often belied the low haemoglobin values which were found.

An attempt to obtain a series of haemoglobin estimations in infants of the upper classes was found to be impracticable owing to the difficultties 
accompanying most investigations of such a nature on private patients. It is, however, of interest to estimate theoretically the incidence of anaemia in infants of the upper classes, by assessing the probable frequency of the etiological factors discussed above. It is clearly established that the diet of the mother has little or no effect on the birth weight of the infant except in cases of the extreme malnutrition which occurs in times of war and famine $^{1 \tau, 4 s, 49}$. Several investigations have revealed no significant correlation between the birth weights of infants and social class ${ }^{50,51,52}$. It may be deduced, therefore, that the incidence of anaemia due to low birth weight alone is similar in the upper and lower classes. Probably the incidence of infections is less in infants of the upper classes, and the dietary regimen after weaning is in most cases more satisfactory. In this connexion it is of interest to note that the incidence of anaemia among the infants in the institution already described was greater than in the large series of outpatient infants. Such a result is surprising in view of the fact that the standard of the dietary regimen and the general management of the infants in the institution is certainly much higher than in poor class infants, and probably excels that of babies of the better classes. It is possible that this finding may be explained by a higher incidence of infective illnesses among infants congregated in an institution.

In conclusion it may be said that whilst anaemia is probably less frequent in infants of the upper classes, it should nevertheless be regarded as of real importance and the rules already laid down for the institution of iron therapy should be observed.

\section{Conclusions}

1. Subnormal haemoglobin levels (haemoglobin less than 80 per cent. Haldane) were present in 87 per cent. of 298 poor-class infants between the ages of nine and twenty-three months.

2. The common anaemia of late infancy is due mainly to iron deficiency which is dependent on low birth weight, artificial feeding and infective illnesses.

3. Probahly infections have the additional effect of producing inhibition of blood formation.

4. Anaemia in infancy depends only to a slight extent, if at all, upon the common degrees of maternal iron deficiency.

5. The incidence of anaemia among infants of the better classes is probably somewhat less than among the poor.

Thanks are due to Professor L. S. P. Davidson for his advice in the preparation of this paper, and to Dr. J. A. Stephen and Dr. Aileen A. Nicol, without whose help and co-operation, the investigation would have been impossible. 


\section{REFERENGES}

1. Mackay, H. M. M., Med. Res. Counc., Spec. Rep. Series, London, 1931, 157.

2. Davidson, L. S. P., Fullerton, H. W., et al., Brit. Med. J., London, 1933, i, 685.

3. Davidson, L. S. P., Fullerton, H. W., \& Campbell, R. M., Brit. Med. J., London, 1935, ii, 195.

4. Josephs, H., Bull. Johns Hopkins Hosp., Baltimore, 1931, XLIX, 246.

5. Parsons, L. G., Hickmans, E. M., \& Hawksley, J. C., Arch. Dis. Childh., London, 1933, VIII, 85.

6. Lewis, M. S., J. Am. Med. Ass., Chicago, 1931, XCVI, 1135.

7. Titus, R. W., \& Hughes, J. S., J. Biol. Chem., Baltimore, 1929, LXXXIII, 463.

8. Scholz, R., Ztschr. f. Kinderheilk., Berlin, 1936, LVIII, 73.

9. Poynton, F., Thursfield, H., \& Paterson, D., Brit. J. Child. Dis., London, 1922, XIX, 57.

10. Parsons, L. G., \& Hawkesley, J. C., Arch. Dis. Childh., London, 1933, VIII, 128.

11. Fullerton, H. W., Brit. Med. J., London, 1936, ii, 523.

12. Sherman, H. C., Chemistry of Food and Nutrition, New York, 1928.

13. Cunningham, I. J., Biochem. J., Cambridge, 1931, XXV, 1267.

14. Wallgren, A., Acta Paediat., Upsala, 1932, XII, 153, 170.

15. Peterson, W. H., \& Elvehjem, C. A., J. Biol. Chem., Baltimore, 1928, LXXVIII, 215.

16. Josephs, H., Bull. Johns Hopkins Hosp., Baltimore, 1934, LV, 259.

17. Langstein, L., \& Edelstein, F., quoted by Committee on Growth and Development of the Child, Part III, Nutrition, New York, 239.

18. Blauberg, M., Ztschr. f. Biol., Munich, 1900, XL, 1.

19. Davidson, L. S. P., \& Leitch, I., Nutrition Abstr. and Rev., Aberdeen, 1934, III, 901.

20. Strauss, M. B., J. Clin. Invest, New York, 1933, XII, 375.

21. Baar, H., \& Stransky, F., Die Klinische Hematologie des Kindersalters, Leipsig, 1928.

22. Parsons, L. G., Brit. Med. J., London, 1933, ii, 631.

23. Paxton, W. T. W., Glasgow Med. J., Glasgow, 1936, CXXV, 153.

24. Strauss, M. B., J. Am. Med. Ass., Chicago, 1934, CII, 281.

25. Bunge, G., quoted by Mackay, H. M. M., Med. Res. Counc., Spec. Rep. Series, London, 1931, 157.

26. Happ, W. M., Bull. Johns Hopkins Hosp., Baltimore, 1922, XXXIII, 163.

27. Mitchell, H. S., \& Vaughan, M., J. Biol. Chem., Baltimore, 1927, LXXV, 123.

28. Harrop, G. A., Medicine, Baltimore, 1928, VII, 291.

29. Lucas, W. P., \& Dearing, B. F., Am. Jour. Dis. Child., Chicago, 1921, XXI, 96.

30. Bakwin, H., \& Rivkin, H., ibid., 1924, XXVII, 340.

31. Darrow, D. C., Soule, H. C., \& Buckman, T. E., J. Clin. Invest., New York, $1928, \mathrm{~V}, 243$.

32. Gladstone, S. A., Am. J. Dis. Child., Chicago, 1932, XLIV, 81.

33. Sheldon, J. H., Brit. Med. J., London, 1932, ii, 869.

34. Toverud, K. U., Acta Paediat., Upsala, 1935, XVII, Supp. No. 1, 136.

35. Growth and Development of the Child, Part III, Nutrition, New York, 233.

36. Josephs, H., Bull. Johns Hopkins Hosp., Baltimore, 1934, LV, 259.

37. Hahn, P. F., \& Whipple, G. H., Am. J. Med. Sci., Philadelphia, 1936, CXCI, 24.

38. Usher, S. J., MacDermott, P. N., \& Lozinski, E., Am. J. Dis. Child., Chicago, 1935, XLIX, 642.

39. Fullerton, H. W., Brit. Med. J., London, 1936, ii, 577.

40. Magnusson, J. H., Acta Paediat., Upsala, 1935, XVIII, Supp. No. 1, 331.

41. Kunckel, D., Ztschr. f. Kinderh., Berlin, 1915, XIII, 101.

42. Abt, A. F., \& Nagel, B. R., J. Am. Med. Ass., Chicago, 1932, XCVIII, 2270.

43. Hugounenq, M. L., see Growth and Development of the Child, Part III, Nutrition, New York, 230. 
44. Ogilvie, J. W., Arch. Dis. Childh., London, 1935, X, 143.

45. Faber, H. K., Mermod, C., Gleason, A. L., \& Watkins, R. P., J. Paediat., St. Louis, 1935, VII, 435.

46. Oliver, T. H., \& Wilkinson, J. F., Quart. J. Med., Oxford, 1933, II, 431.

47. Leitch, I., Nutrit. Abstr. and Rev., Aberdeen, 1932, II, 451.

48. Abels, H., Ztschr. f. Kinderh., Berlin, 1932, LII, 31.

49. Garry, R. C., \& Stiven, D., Nutrit. Abstr., and Rev., Aberdeen, 1935-36, V, 855.

50. Bivings, L., Am. J. Obstet. Gyn., St. Louis, 1934, XXVII, 725.

51. Brend, W. A., Med. Res. Counc., Spec. Rep. Series, London, 1918, 10.

52. Murray, M. B., ibid., 1924, 81. 